\title{
Yield and Quality Performance of Italian and American Strawberry Genotypes in Brazil
}

\author{
Maria I. Diel ${ }^{1}$, Marcos V. Marques Pinheiro ${ }^{2}$, Carine Cocco $^{3}$, Braulio O. Caron², Daniele C. Fontana ${ }^{2}$, \\ Daniela Meira ${ }^{2}$, Leonardo A. Thiesen ${ }^{2} \&$ Denise Schmidt ${ }^{2}$ \\ ${ }^{1}$ Crop Science Department, Federal University of Santa Maria, Santa Maria, Brazil \\ ${ }^{2}$ Department of Agronomic and Environmental Sciences, Federal University of Santa Maria, Frederico \\ Westphalen Campus, Frederico Westphalen, Brazil \\ ${ }^{3}$ University of Caxias do Sul, Rio Grande do Sul, Brazil \\ Correspondence: Marcos V. Marques Pinheiro, Department of Agronomic and Environmental Sciences, Federal \\ University of Santa Maria, Frederico Westphalen Campus, Frederico Westphalen, Brazil. E-mail: \\ macvini@gmail.com \\ Denise Schmidt, Department of Agronomic and Environmental Sciences, Federal University of Santa Maria, \\ Frederico Westphalen Campus, Frederico Westphalen, Brazil. E-mail: denise@ufsm.br
}

Maria I. Diel, Crop Science Department, Federal University of Santa Maria, Santa Maria, Brazil. Tel: 55-981-268-497. E-mail: mariaines.diel@hotmail.com

Received: October 31, 2017

Accepted: December 6, 2017 Online Published: January 15, 2018

doi:10.5539/jas.v10n2p139

URL: https://doi.org/10.5539/jas.v10n2p139

\begin{abstract}
The strawberry cultivars show variation in agronomic performance when grown in different regions of the world, due to the genotype $\times$ environment interaction. The aim of the study was to evaluate the yield performance and quality of Italian and American strawberry cultivars. We evaluated the phyllochron, which measures the time required for the emission of successive leaves in a plant, the number and commercial and non-commercial fruit yield, titratable acidity and total soluble solids (obtained from evaluations of the Brix degree of the fruit). The experimental design was a randomized complete block with 11 treatments, which were composed of the Italian strawberry cultivars (CREA-FRF PIR 29, CREA-FRF PA3, CREA-FRF CE 51, CREA-FRF CE 56, CREA-FRF Jônica and CREA-FRF Pircinque) and American (Albion, Camarosa, San Andreas, Camino Real and Aromas), with four replications per treatment, eight plants per plot, giving a total 32 plants per cultivar. Analysis of variance showed differences for phyllochron, marketable fruits yield and total soluble solids content. The American cultivar Albion showed higher phyllochron, the cultivar CREA-FRF Pircinque the lowest phyllochron. The highest yields of marketable fruits were found in American cultivars Camino Real and CREA-FRF Pircinque. The higher solids soluble was observed in Italian cultivars. Thus, we highlight the Italian strawberry cultivars, because they reflect good yield when compared to the American cultivars.
\end{abstract}

Keywords: Fragaria $\times$ ananassa, environment, phyllochron, Italian and American cultivars

\section{Introduction}

The main strawberry (Fragaria $\times$ ananassa) producers worldwide are China, United States, Spain and Japan, which together produced 4949479.00 tons of the fruit (FAOSTAT, 2017). The Brazil produced in 2014 about 3527 tons of strawberry (FAOSTAT, 2017), distributed in the states of Minas Gerais, Rio Grande do Sul, Paraná, Santa Catarina, São Paulo, Espírito Santo, Distrito Federal, Bahia and Ceará. The strawberry crop (Fragaria $\times$ ananassa) had great development in the last decade due to its high return and possibilities of transformation in the cultivation process (Rigon, 2015). Usually, the crop yield varies according to several variables, such as cultivar, production system, management culture and local cultivation which are able to influence the profitability of production. For this, the cultivars have been evaluated for acclimatization to different regions, which wouldl contribute to the lower production costs (Dávalos-González et al., 2014).

In addition to the strawberry yield, the nutritional and organoleptic characteristics of fruits must be taken into account (Fernandez-Lara et al., 2015), because the content of the compounds may vary depending on the genotype (Kosinska et al., 2013) and environmental factors (Krüger et al., 2012; Ulrich \& Olbricht, 2014). The 
production and the size of the strawberry fruits are influenced by genotype characteristics, planting season, as well as its interaction with meteorological conditions (Rahman et al., 2014; Zheng et al., 2009), which stimulate the ideal conditions for plant growth, contributing to increased or reduced crop yield. However, there is still little research on sensory and nutritional analysis of cultivars in growing regions.

The cultivation environment, the production system, temperature and solar radiation may modify the plant phenology, requiring its knowledge in order to determine planting season and requirement of meteorological variables for a better development and expression of agronomic traits of different cultivars (Rosa et al., 2013; Costa et al., 2014; Tazzo et al., 2015). Thus, it comes to using the phyllochron to measure the time required for issuing successive leaves on a plant (Hermes et al., 2001), taking into account the effect of temperature on the plant development (Streck et al., 2005).

Thus, the aim of this study was to evaluate the performance and yield components of Italian and American strawberry cultivars including phyllochron and fruit quality.

\section{Material and Methods}

The work was conducted under low tunnels (height 0.6 meters, with distance between arches of 2 meters, covered with plastic of 100 microns) in the experimental field of the Federal University of Santa Maria, Frederico Westphalen campus, Frederico Westphalen, Rio Grande do Sul, Brazil, located geographically at $27^{\circ} 23^{\prime} 728^{\prime \prime} \mathrm{S}$ and $53^{\circ} 25^{\prime} 749^{\prime \prime} \mathrm{E} 493$ meters of altitude.

The soil of the experimental area is classified as Red Latosol dystrophic typic with clay texture, deep and well drained (Embrapa, 2006). The climate is Cfa by the Köppen climate classification, being subtropical humid, characteristics of rainy subtropical with an average annual precipitation high and well distributed throughout the year, with mean for anual. Land preparation was carried out with a disc plow and harrowed using a disk harrow. Fertilizer rates were applied according to the previous soil analysis and calculated according to the culture requirements (Santos \& Medeiros, 2003). Cattle manure was incorporated into the soil $\left(5.5 \mathrm{~kg} \mathrm{~m}^{-2}\right)$ and before planting, we used a dose of $55 \mathrm{~g} \mathrm{~m}^{-2}$ chemical fertilizer (10-20-10).

The Italian seedlings were planted on the $6^{\text {th }}$ of May 2015. And the American cultivars were transplanted on June $3^{\text {rd }}$ to Camino Real, June $2^{\text {nd }}$ to Camarosa, June $8^{\text {th }}$ to Albion, and the San Andreas and Aromas cultivars were transplanted on June $22^{\text {nd }}$ of this year. The planting dates followed the delivery schedule of the seedlings by nursery owners and importers organs, since most of seedlings used in Brazil for the implementation of crops, are from nurseries located in Chile and Argentina. The irrigation and fertigation were made through drip tape, following with cultural practices in accordance with the requirements of the culture.

The experimental design was a randomized complete block with 11 treatments, which were composed of the Italian strawberry cultivars (CREA-FRF PIR 29, CREA-FRF PA3, CREA-FRF CE 51, CREA-FRF CE 56, CREA-FRF Jônica and CREA-FRF Pircinque) and American (Albion, Camarosa, San Andreas, Camino Real and Aromas), with four replications per treatment, eight plants per plot, giving a total 32 plants per cultivar. The Italian cultivars used in this study came from an agreement between Brazil and Italy, from the Convention for experimentation and dissemination of genetic material from Italian strawberry in Brazil. The agreement was signed in 2012 between the Agroveterinárias Sciences Center at the University of the State of Santa Catarina UDESC and 'Consiglio per la Ricerca in Agricoltura and L'analisi dell'Economia Agraria' - Unità di Ricerca per la Fruticultura (CREA-FRF) from Italy.

The average air temperature was carried out using a data logger where the minimum and maximum air temperatures data inside the low tunnels was captured. The following formula was used to calculate the mean air tempertaure, where $\mathrm{T}$ represent the temperature:

$$
\text { Tave }=\operatorname{Tmax}+\operatorname{Tmin} / 2
$$

Based on the average air temperature, the daily thermal time (DTt) was calculated according to the following aquation (Arnold, 1960):

$$
D T t=(\text { Tave }-T b) \cdot 1 \text { day } \quad\left\{{ }^{\circ} \mathrm{C} \text { day }\right\}
$$

The base temperature $(\mathrm{Tb})$ is defined as the daily thermal time units above a lower base temperature, below which the plant does not grow or its development is so slow that it can be ignored (Rosa et al., 2011), for the strawberry evaluation a $7^{\circ} \mathrm{C}$ as a base temperature (Mendonça et al., 2012).

Then, we calculated the accumulated thermal time (ATt), which is the sum of DTt:

$$
A T t=\sum D T t \quad\left\{{ }^{\circ} \mathrm{C} \text { day }\right\}
$$


During the crop growing cycle, the following variables were evaluated: phyllochron, number of commercial fruits (NCF) and non-commercial (NNCF), commercial fruits yield (CFY) and non-commercial (NCFY), titratable acidity (TA), total soluble solids (TSS), and ratio of total soluble solids and titratable acidity (TSS/TA).

For phyllochron variable, the number of leaves was counted in the crown every three days since the issuance of the leaves to full bloom, period in which the plant emits the second floral raceme (Mendonça et al., 2012). For the count was considered a leaf, when it had become visible and the borders of the leaflet no longer touched. To estimate the phyllochron, there was realized the linear regression between the number of crown leaves and the thermal time, being the inverse of the angular coefficient of the linear regression (Mendonça et al., 2012).

The fruits were harvested twice a week, at complete maturity phase, performing the separation of commercial and non-commercial fruits. For this, it was considered as non-commercial fruit that had deformations or weight less than $6.0 \mathrm{~g}$. Thus, it was generated two variables: number and production of commercial and non-commercial frutis.

Qualitative analysis in fruits was carried out throughout the cycle, in order to eliminate specific characteristics of the harvest season. The titratable acidity and total soluble solids were analyzed in the laboratory. Determination of total acidity titration was performed with a standardized solution of $\mathrm{NaOH} 0.1 \mathrm{~mol} \mathrm{~L}^{-1}$, and the determination of total soluble solids using a manual refractometer ( ${ }^{\circ}$ Brix).

The data was subjected to analysis of variance and means were separated by Duncan test at $5 \%$ error probability. Pearson correlation analysis was conducted for all the variables using statistical software Genes (Cruz, 2013).

\section{Results and Discussion}

The following is the average air temperature, maximum and minimum registered inside the low tunnels during the experiment. The maximum and minimum temperature recorded inside the tunnels during the conduction of the experiment, between may and december was 46.6 and $-0.7{ }^{\circ} \mathrm{C}$ respectively. The average temperature oscillated during the production cycle ranging from $10-30{ }^{\circ} \mathrm{C}$ (Figure 1).

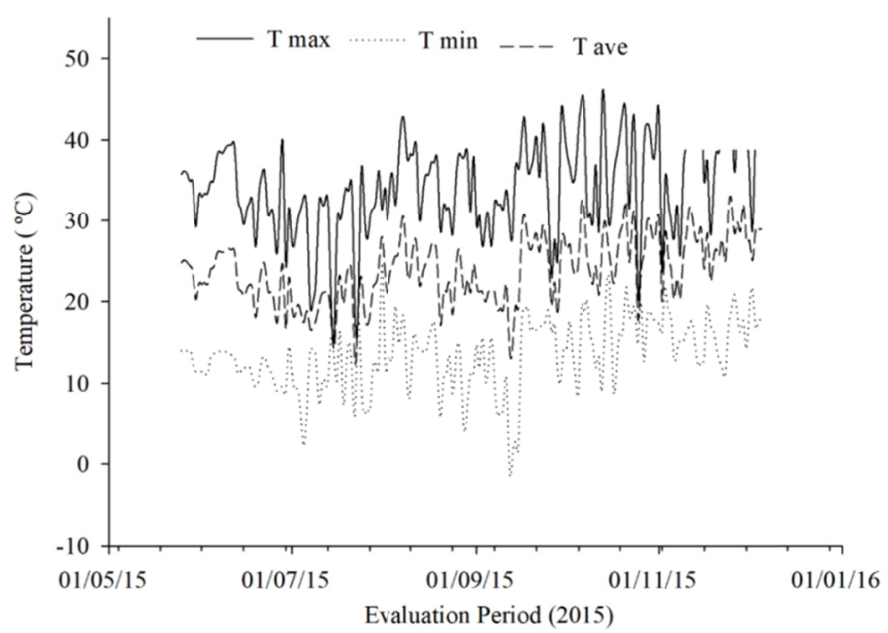

Figure 1. Average air temperature, maximum and minimum registered inside the protected environment during the period of the experiment with strawberry cultivars

The strawberry cultivars have different temperature requirements for its development (Rosa et al., 2011; Mendonça et al., 2012), which makes it the main limiting factor for this crop, because it affects plant development, production and quality fruits (Serçe \& Hancock, 2005). For example, critical air temperature for the culture may compromise flowering, when above $25{ }^{\circ} \mathrm{C}$ (Brazanti, 1989). The same authors report that the floral differentiation of strawberry plants is inhibited at temperatures above $32{ }^{\circ} \mathrm{C}$, which may occur floral abortions and excessive production losses. Similarly, high temperatures, hydric deficit and low solar radiation cause floral abscission, which may reduce the number of fruit (Wang \& Camp, 2000).

For floral induction in strawberry plants to occur, low temperatures are required, which then results in abundant flowering. Additionally, in these conditions, the temperature with day length acting in the differentiation of vegetative to a floral meristem (Lieten, 2005) in short day cultivars. At the same time, the shoot plant may have 
greater development through cultivation protected, as will enable the control of climate conditions inside, keeping them in vegetable comfort zone (Singh et al., 2012).

The analysis of variance showed meaningful results for phyllochron, commercial fruit yield and content of total soluble solids (Figure 2). The variable number of commercial and non-commercial fruits, non-comercial fruits yield and titratable acidity showed similar response for all cultivars, no presenting meaningful differences between them (data not shown).

For phyllochron variable, the late cultivar was Albion $\left(153.09^{\circ} \mathrm{C}\right.$ leaf $\left.{ }^{1}\right)$, and this is not different from Camarosa, San Andreas, Camino Real, CREA-FRF PIR 29 and CREA-FRF CE 51 cultivars, lower capacity of these issue leaves (Figure 2A). In a study conducted with the cultivar Albion in Santa Catarina, Tazzo et al., (2015) observed phyllochron $135.61{ }^{\circ} \mathrm{C}$ leaf ${ }^{1}$. In this study, the earliest cultivar was CREA-FRF Pircinque $\left(80.30{ }^{\circ} \mathrm{C}\right.$ leaf $\left.{ }^{1}\right)$ and did not differ from PA 3, CREA-FRF Jônica, CREA-FRF CE 56 and Aromas cultivars (Figure 2A). Cultivars with higher value phyllochron are less efficient in transforming the photosynthetic energy, which reflects a lesser accumulation of reserve substances to strawberry, influencing the agronomic yield (Tazzo et al., 2015).
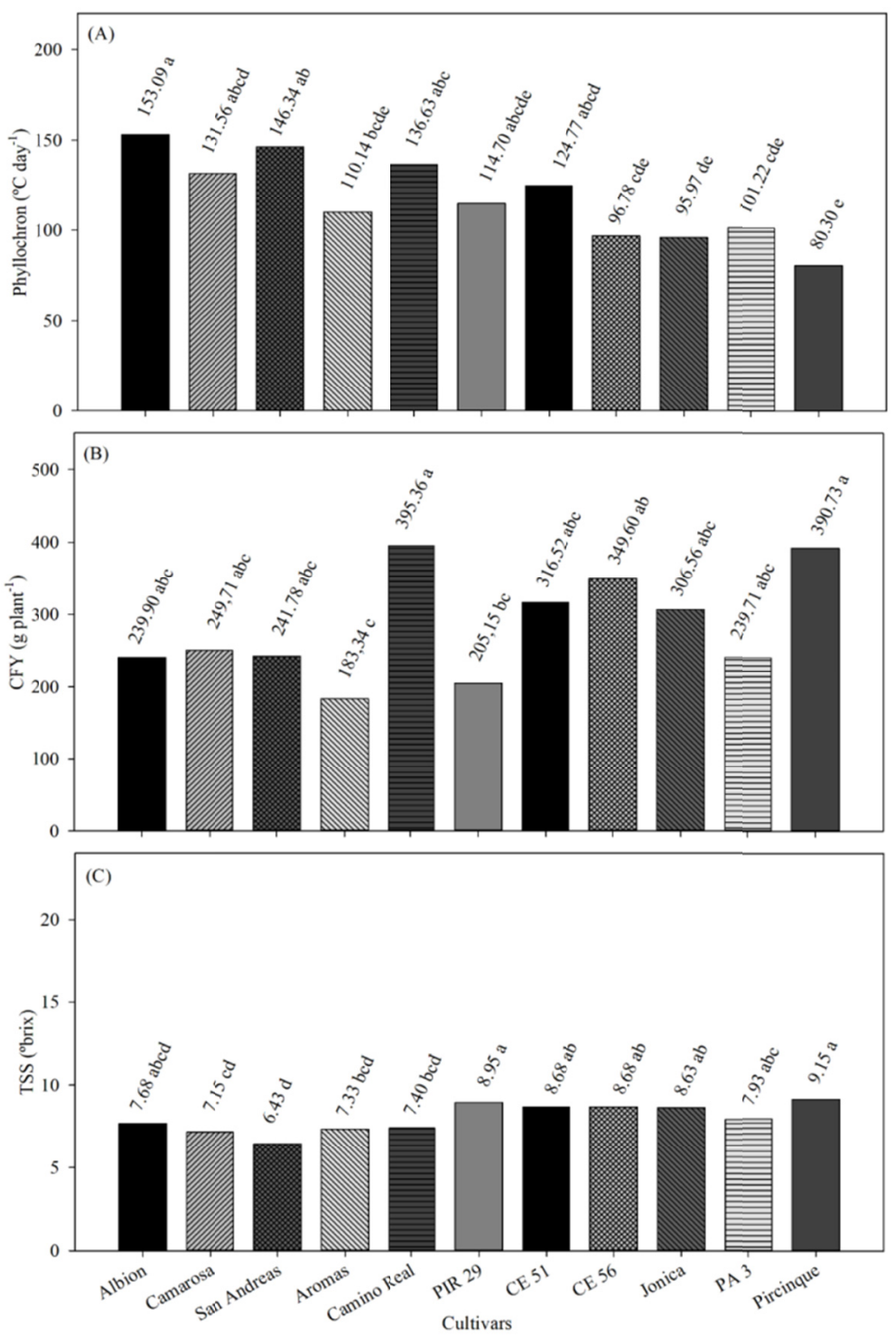

Figure 2. Phyllochron (A); commercial fruits yield, CFY (B); and total soluble solids, TSS (C) of American and Italian strawberry cultivars in semi-hydroponic cultivation under low. Means followed by the same letter do not differ by Duncan test at $5 \%$ error probability 
According to Tazzo et al. (2015), when tested strawberry cultivars and Italian selections, it was noted that selections from Italy ("SEL1" and "SEL2") met the smaller phyllochron values $\left(69.96\right.$ and $70.22{ }^{\circ} \mathrm{C}$ day leaf ${ }^{1}$, respectively), inferring these cultivars greater amount of leaves and physiological activities. The same happened in this work, in which there was the greatest precocity in CREA-FRF Pircinque, which resulted in greater numbers of leaves when compared to the other cultivars (Figures 3 and 4).

In the south of Brazil, Mendonça et al. (2012) observed phyllochron values of $149.34 \pm 31.3{ }^{\circ} \mathrm{C}$ day leaf ${ }^{1}$ to Albion cultivar, $112.40 \pm 10.15^{\circ} \mathrm{C}$ day leaf ${ }^{1}$ to Camino Real and $86.34 \pm 34.73{ }^{\circ} \mathrm{C}$ day leaf ${ }^{1}$ to Ventana. That is, the differences between genotypes and their interaction in certain areas may cause changes in the plant cycle (Tazzo et al., 2015) indicating that they have specific genotype. Some strawberry cultivars show variability in leaf appearance rate and, consequently, in phyllochron (Mendonça et al., 2012; Rosa et al., 2011). However, between the factors cultivar and planting season, the variation of phyllochron is more affected by the environment than by genetic of strawberry cultivars, it may vary in different crop regions (Rosa et al., 2011). Thus, justified the few differences for most cultivars used.

In the present work, less amount of leaves in American cultivars (Figure 3) compared to Italian culivars (Figure 4) was observed.
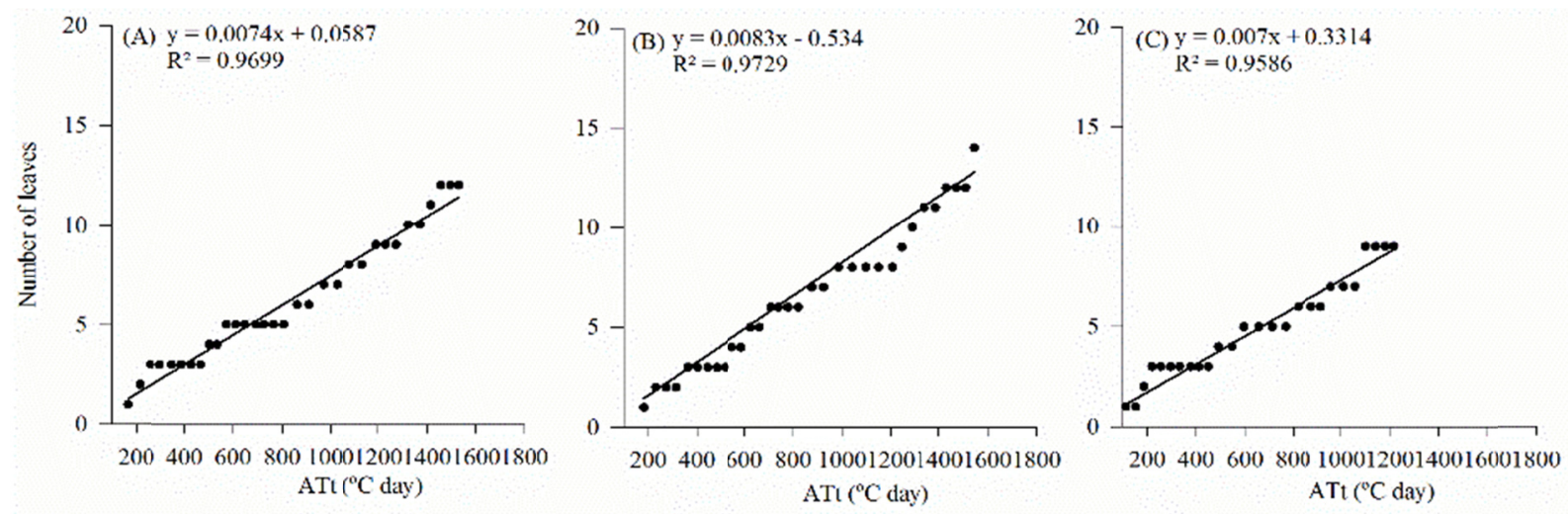

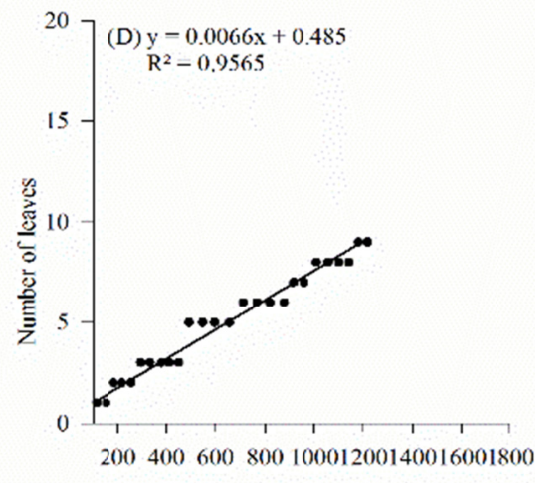

ATt ("C day)

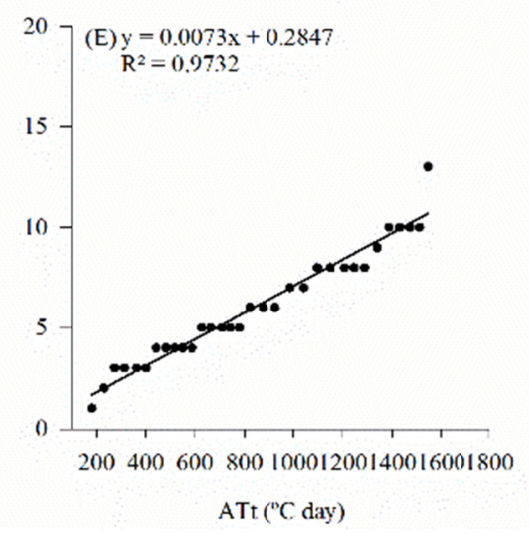

Figure 3. Linear regression performed between the number of leaves in the crown and the thermal time in American strawberry cultivars Albion (A); Camarosa (B); San Andreas (C); Aromas (D); and Camino Real (E) 

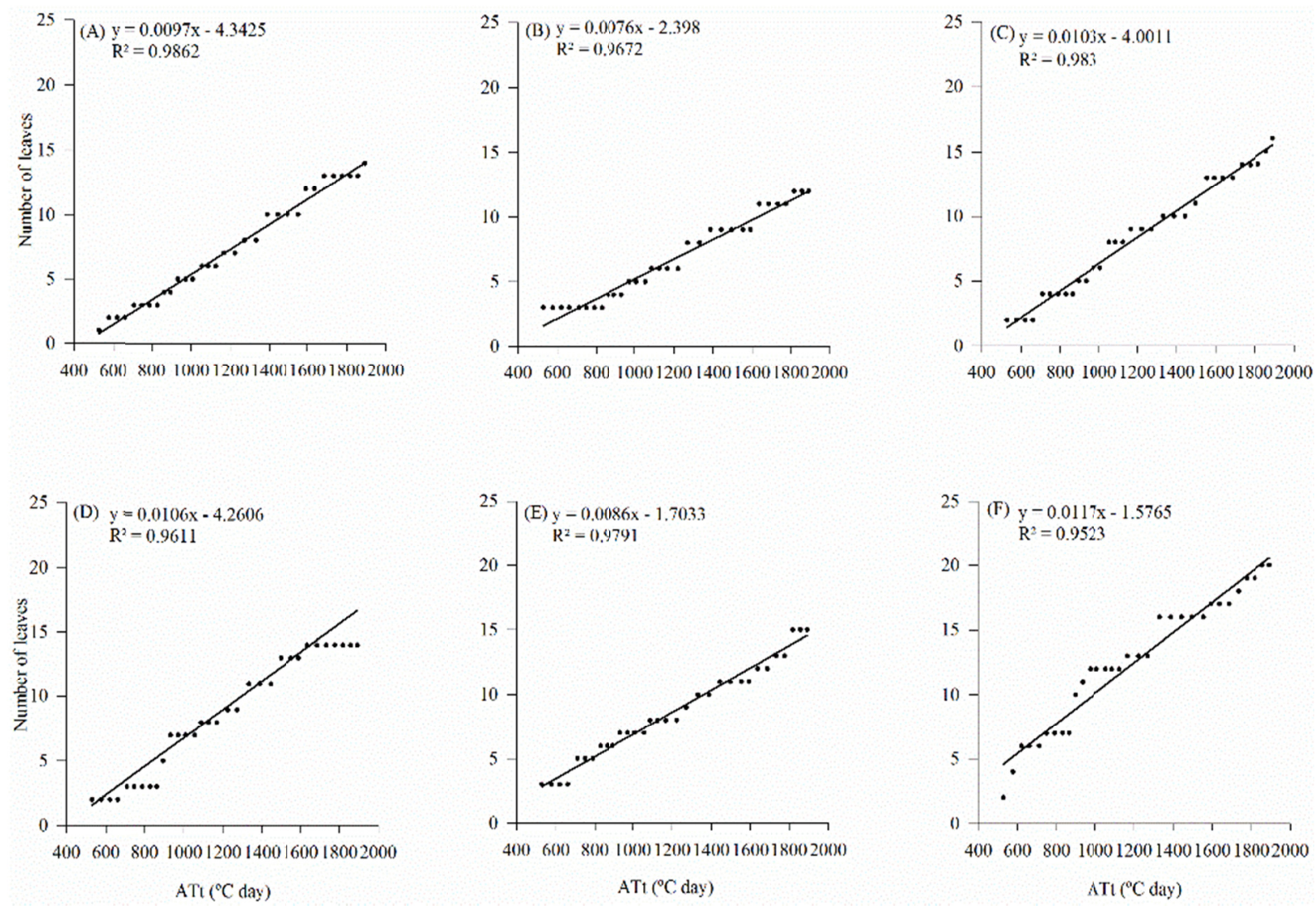

Figure 4. Linear regression performed between the number of leaves in the crown and the thermal time in Italian strawberry cultivars CREA-FRF PIR 29 (A); CREA-FRF CE 51 (B); CREA-FRF CE 56 (C); CREA-FRF Jônica (D); PA 3 (E); CREA-FRF Pircinque (F)

The commercial fruits yield showed differences among cultivars, and the most productive were Camino Real and CREA-FRF Pircinque, which showed average yield of 395.36 and 390.73 g plant $^{-1}$, respectively. The American cultivar Aromas was less productive (Figure 2B).

In southern Italy, high production values were observed in CREA-FRF Pircinque cultivar compared to the Sabrosa Candonga and Camarosa cultivars (Fagherazzi et al., 2012). In the present work, the yield results for the Camarosa cultivar are smaller than those reported by Costa et al. (2011) also in the south of Brazil (Passo Fundo/RS), , and similar to those found by Passos et al. (2015) in the southeastern region of Brazil, Campinas/SP. In general, the cultivars yield showed low performance, due to the high temperatures expressed during crop production cycle (Figure 1). The elevated temperature can cause flower abortion and, consequently, decreased fruit number (Wang \& Camp, 2000). Thus, in the present work the high temperatures, above $40{ }^{\circ} \mathrm{C}$, may have caused reduction in the emission of flowers, resulting in low yield. Furthermore, the high relative humidity, prolonged periods of precipitation and the use of low tunnels may have contributed to the formation of an appropriate microclimate for the development of foliar diseases causing meaningful reduction in yield, as the strawberry is very susceptible to pests and diseases.

In the present work, there was higher total soluble solids (TSS) contents in the CREA-FRF Pircinque and CREA-FRF PIR 29 cultivars, and these did not differ from CREA-FRF CREA-FRF CE 51, CREA-FRF CE 56, CREA-FRF Jônica, PA 3 and Albion cultivars. The lower performance was observed in the San Andreas cultivar, which did not differ from Camarosa, Aromas and Camino Real (Figure 2C). Usually, the amount of TSS and Brix levels differ between strawberry cultivars (Cao et al., 2015; Silva et al., 2015).

Correia et al. (2011) found for fruit of Ventana cultivar, in Portugal, lower values of TSS in several sampling dates, compared to fruit Candonga and Camarosa 6.23 and $10.35^{\circ}$ Brix, respectively. To Albion cultivar, there are reports of $7.8^{\circ}$ Brix content in protected crop in Shenyang, China (Cao et al., 2015), and 8.4 to $9{ }^{\circ}$ Brix in fruits that were grown in low tunnels in Chihuahua, México (Ornelas-Paz et al., 2013). Differences among 
genotypes were found in Bangladesh, where fruits of Camarosa (8.41\%) had the highest TSS contente (Rahman et al., 2014). In Vrbovec, Croatia, the Albion cultivar showed higher TSS content in relation to the Monterey, Capri and Murano cultivars in hydroponic crop (Samec et al., 2016). Cao et al. (2015) reported that genetic factors and environmental conditions influence the flavor and fruit quality (as measured by soluble solids and titratable acidity). The soluble sugars are products derived directly from the photosynthesis and the differences in sugar content reflects indirectly higher photosynthetic efficiency (Yu et al., 2015), and may list phyllochron plant with TSS, the lower the phyllochron the greater the number of leaves, reflected in higher photosynthetic and productive efficiency. For example, in the present work, CREA-FRF Pircinque cultivar showed lower phyllochron, higher leaf emission rate, and probably higher photosynthetic rate, that resulted in greater productive efficiency and higher total soluble solids content (Table 1).

Table 1. Correlation coefficients between phyllochron variables, yield and quality of fruit grown strawberry cultivars under low tunnels in northern region of Rio Grande do Sul, Brazil

\begin{tabular}{lllllllll}
\hline & Phyllochron & NCF & CFY & NNCF & NCFY & TA & TSS & TSS/TA \\
\hline Phyllochron & - & $-0.60^{*}$ & $-0.30^{\text {ns }}$ & $-0.59^{\text {ns }}$ & $-0.02^{\text {ns }}$ & $0.65^{*}$ & $-0.70^{*}$ & $-0.75^{*}$ \\
NCF $^{1}$ & - & - & $0.59^{\text {ns }}$ & $0.94^{*}$ & $0.09^{\text {ns }}$ & $-0.44^{\text {ns }}$ & $0.52^{\text {ns }}$ & $0.63^{*}$ \\
CFY & - & - & - & $0.67^{*}$ & $0.72^{*}$ & $-0.10^{\text {ns }}$ & $0.38^{\text {ns }}$ & $0.31^{\text {ns }}$ \\
NNCF & - & - & - & - & $0.30^{\text {ns }}$ & $-0.56^{\text {ns }}$ & $0.67^{*}$ & $0.75^{\text {ns }}$ \\
NCFY & - & - & - & - & - & $-0.02^{\text {ns }}$ & $0.22^{\text {ns }}$ & $0.10^{\text {ns }}$ \\
TA & - & - & - & - & - & - & $-0.58^{\text {ns }}$ & $-0.84^{*}$ \\
TSS & - & - & - & - & - & - & - & $0.90^{*}$ \\
TSS $/$ TA & - & - & - & - & - & - & - & -
\end{tabular}

Note. NCF: number of comercial fruits; CFY: comercial fruits yield; NNCF: number of non-comercial fruits; NCFY: non-comercial fruits yield. TA: titrable acidity; TSS: total soluble solids; TSS/TA: ratio of total soluble solids and titratable acidity.

ns $=$ non-meaningful; $*$ = meaningful to $5 \%$ of error probability.

The Pearson correlation analysis indicated strong and positive meaningful correlation of Phyllochron with the AT variable, strong negative correlation with TSS, strong negative correlation with ratio TSS/TA, in addition to NCF, indicating that the higher the phyllochron (less the number of leaves), the greater the total acidity of the plant and the smaller the amount of sugars, due to reduced photosynthetic capacity of the plant. The same was observed for the NCF, which was lower the higher the phyllochron, reflecting the lower assimilates translocation capacity for the fruit yield.

Meaningful and positive correlation was also observed between NCF and NNCF and TSS/AT, inferring that larger commercial fruit values also increase the amount of NNCF and decreased TA fruits. The CFY variable showed a meaningful positive correlation with the NNCF and NCFY variables, because as it increases the production of commercial fruits it also increases the number and the production of non-comercial fruits. In the same way, TA and TSS variables showed negative and positive correlation respectively with the variables TSS/TA, that is, fruit with higher titratable acidity (TA) had lower TSS/TA, and fruits with higher TSS presented positive relationship with TSS/TA (Table 1).

Thus, must be search alternatives that increase the leaf area and leaf emission rate in order to produce fruit with lower total acidity and higher soluble solids content, because these are a direct product of photosynthesis, and differences in sugar content also reflects indirectly on the higher photosynthetic efficiency (Yu et al., 2015).

The Italian cultivars, especially the cultivar CREA-FRF Pircinque, realised higher yields when compared to the American cultivars. It is concluded that the evaluated cultivars differ for the yield and fruit quality variables.

\section{References}

Arnold, C. Y. (1960). Maximum-Minimum temperature as a basis for computing heat units. Americam Society for Horticulture Science, 76, 682-692.

Brazanti, E. C. (1989). La Fresa (p. 386). Madri, Mundiprensa. 
Cao, F., Guan, C., Dai, H., Li, X., \& Zhang, Z. (2015). Soluble solids content is positively correlated with phosphorus content in ripening strawberry fruits. Scientia Horticulturae, 195, 183-187. https://doi.org/ 10.1016/j.scienta.2015.09.018

Correia, P. J., Pestana, M., Martinez, F., Ribeiro, E., Gama, F., Saavedra, T., \& Palencia, P. (2011). Relationships between strawberry fruit quality attributes and crop load. Scientia Horticulturae, 130, 398-403. https://doi.org/10.1016/j.scienta.2011.06.039

Costa, R. C., Calvete, E. O., Mendonca, H. F. C., \& de Costa, L. (2014). Phenology and leaf accumulation in vernalized and non-vernalized strawberry seedlings in neutral-days. Acta Scientiarum Agronomy, 36, 57-62. https://doi.org/10.4025/actasciagron.v36i1.17285

Costa, R. C., Calvete, E. O., Reginatto, F. H., Cecchetti, D., Loss, J. T., Rambo, A., \& Tessaro, F. (2011). Telas de sombreamento na produção de morangueiro em ambiente protegido. Horticultura Brasileira, 29, 98-102. https://doi.org/10.1590/S0102-05362011000100016

Dávalos-González, P. A., Narro-Sánchez, J., Jofre-Garfias, A. E., Vázquez-Sánchez, M. N., \& Hernández-Razo, A. R. (2014). Yield performance assay and fruit quality of strawberry genotypes tolerant and susceptible to Fusarium oxysporum and to a viral complex. Acta Horticulturae, 1049, 263-266. https://doi.org/10.17660/ ActaHortic.2014.1049.131

Embrapa (Empresa Brasileira de Pesquisa Agropecuária). (2006). Sistema Brasileiro de Classificação de Solos (2nd ed., p. 412). Rio de Janeiro, Embrapa SPI.

Fagherazzi, A. F., Cocco, C., Antunes, L. E. C., Faedi, W., Baruzzi, G., \& Ruffato, L. (2012). CREA-FRF Pircinque: Nova cultivar de morangueiro italiano. XXII Congresso Brasileiro de Fruticultura. Bento Gonçalves, Rio Grande do Sul, Brazil.

FAOSTAT. (2017). Food and Agriculture Organization of the United Nations Statistics Division. Retrieved November 23, 2017, from http://faostat3.fao.org/browse/q/qc/e

Fernández-Lara, R., Gordillo, B., Rodríguez-Pulido, F. J., González-Miret, M. L., Villar-Martínez, A. A., \& Dávila-Ortiz, G. (2015). Assessment of the differences in the phenolic composition and color characteristics of new strawberry (Fragaria $\times$ ananassa Duch.) cultivars by HPLC-MS and imaging tristimulus colorimetry. Food Research International, 76, 645-65. https://doi.org/10.1016/j.foodres.2015.07.038

Hermes, C. C., Medeiros, S. L. P., Manfron, P. A., Caron, B., Pommer, S. F., \& Bianchi, C. (2001). Emissão de folhas de alface em função da soma térmica. Revista Brasileira de Agrometeorologia, 9, 269-275.

Kosinska, A., Diering, S., Prim, D., Heritier, J., \& Andlauer, W. (2013). Phenolic compounds profile of strawberry fruits of Charlotte cultivar. Journal of Berry Research, 3, 15-23. https://doi.org/10.3233/ JBR-130043

Krüger, E., Josuttis, M., Nestby, R., Toldam-Andersen, T. B., Carlen, C., \& Mezzetti, B. (2012). Influence of growing conditions at different latitudes of Europe on strawberry growth performance yield and quality. Journal of Berry Research, 2, 143-157. https://doi.org/10.3233/JBR-2012-036

Lieten, P. (2005). Strawberry production in central Europe. International Journal of Fruit Science, 5, 91-105. https://doi.org/10.1300/J492v05n01_09

Mendonça, H. F. C., Calvete, E. O., Nienow, A. A., Costa, R. C., Zerbielli, L., \& Bonafé, M. (2012). Phyllochron estimation in intercropped strawberry and monocrop systems in a protected environment. Revista Brasileira de Fruticultura, 34, 15-23. https://doi.org/10.1590/S0100-29452012000100005

Ornelas-Paz, J. J., Yahia, E. M., Ramírez-Bustamante, N., Pérez-Martínez, J. D., Escalante-Minakata, M. P., Ibarra-Junquera, V., \& Ochoa-Reyes, E. (2013). Physical attributes and chemical composition of organic strawberry fruit (Fragaria $\times$ ananassa Duch cv. Albion) at six stages of ripening. Food Chemistry, 138, 372-381. https://doi.org/10.1016/j.foodchem.2012.11.006

Passos, F. A., Trani, P. E., \& Carvalho, C. R. L. (2015). Desempenho agronômico de genótipos de morangueiro. Horticultura Brasileira, 33, 267-271. https://doi.org/10.1590/S0102-053620150000200021

Rahman, M. M., Rahman, M. M., Hossain, M. M., Khaliq, Q. A., \& Moniruzzaman, M. (2014). Effect of planting time and genotypes growth, yield and quality of strawberry (Fragaria $\times$ ananassa Duch.). Scientia Horticulturae, 167, 56-62. https://doi.org/10.1016/j.scienta.2013.12.027

Rigon, L. (2015). Anuário Brasileiro da Fruticultura (p. 104). Santa Cruz do Sul, Editora Gazeta Santa Cruz. 
Rosa, H. T., Streck, N. A., Walter, L. C., Andriollo, J. L., \& Silva, M. R. (2013). Crescimento vegetativo e produtivo de duas cultivares de morango sob épocas de plantio em ambiente subtropical. Revista Ciência Agronômica, 44, 604-613. https://doi.org/10.1590/S1806-66902013000300024

Rosa, H. T., Walter, L. C., Streck, N. A., Andriollo, J. L., Silva, M. R., \& Langne, J. Á. (2011). Base temperature for leaf appearance and phyllochron of selected strawberry cultivars in a subtropical environment. Bragantia, 70, 939-945. https://doi.org/10.1590/S0006-87052011000400029

Samec, D., Maretic, M., Lugaric, I., Mesic, A., Salopek-Sondi, B., \& Duralija, B. (2016). Assessment of the differences in the physical chemical and phytochemical properties of four strawberry cultivars using principal component analysis. Food Chemistry, 194, 828-834. https://doi.org/10.1016/j.foodchem.2015. 08.095

Santos, A. M., \& Medeiros, A. R. M. (2003). Morango: Produção. Frutos do Brasil (p. 81). Embrapa Clima Temperado.

Serçe, S., \& Hancock, J. F. (2005). The temperature and photoperiod regulation of flowering and runnering in the strawberries, Fragaria chiloensis, F. virginiana, and F. × ananassa. Scientia Horticulturae, 103, 167-177. https://doi.org/10.1016/j.scienta.2004.04.017

Silva, M. S., Dias, M. S. C., \& Pacheco, D. D. (2015). Desempenho produtivo e qualidade de frutos de morangueiros produzidos no norte de Minas Gerais. Horticultura Brasileira, 33, 251-256. https://doi.org/ $10.1590 / \mathrm{S} 0102-053620150000200018$

Streck, N. A., Bellé, R. A., Rocha, E. K., \& Schuh, M. (2005). Estimating leaf appearance rate and phyllochron in safflower (Carthamus tinctorius L.). Ciência Rural, 35, 1448-1450. https://doi.org/10.1590/S0103-847 82005000600036

Tazzo, I. F., Fagherazzi, A. F., Lerin, S., Kretzschmar, A. A., \& Rufato, L. (2015). Exigência térmica de duas seleções e quatro cultivares de morangueiro cultivado no planalto catarinense. Revista Brasileira de Fruticultura, 37, 550-558. https://doi.org/10.1590/0100-2945-097/14

Ulrich, D., \& Olbricht, K. (2014). Diversity of metabolite patterns and sensory characters in wild and cultivated strawberries. Journal of Berry Research, 4, 11-17. https://doi.org/10.3233/JBR-140067

Wang, S. Y., \& Camp, M. J. (2000). Temperatures after bloom affect plant growth and fruit quality of strawberry. Scientia Horticulturae, 85, 183-199. https://doi.org/10.1016/S0304-4238(99)00143-0

Yu, J., Wanga, M., Donga, C., Xiea, B., Liua, G., Fua, Y., \& Liu, H. (2015). Analysis and evaluation of strawberry growth photosynthetic characteristics biomass yield and quality in an artificial closed ecosystem. Scientia Horticulturae, 195, 188-19. https://doi.org/10.1016/j.scienta.2015.09.009

\section{Copyrights}

Copyright for this article is retained by the author(s), with first publication rights granted to the journal.

This is an open-access article distributed under the terms and conditions of the Creative Commons Attribution license (http://creativecommons.org/licenses/by/4.0/). 